FLOW STUDIES FOR RECYCLING METAL COMMODITIES IN THE UNITED STATES

\title{
Lead Recycling in the United States in 1998
}

\author{
By Gerald R. Smith
}




\section{CONTENTS}

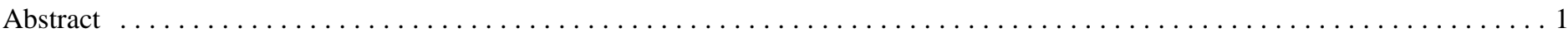

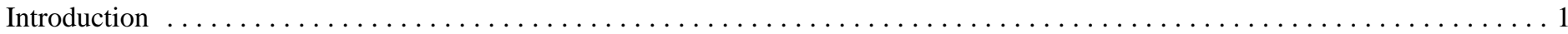

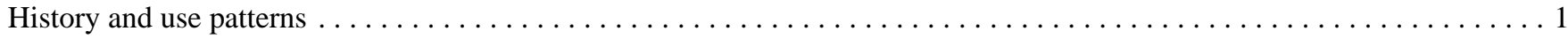

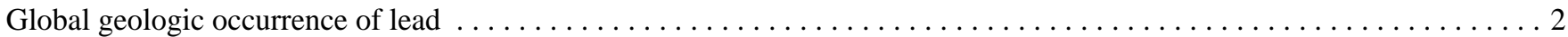

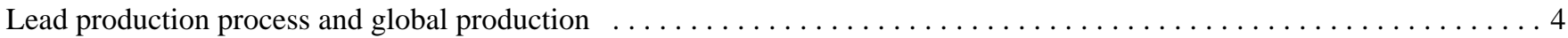

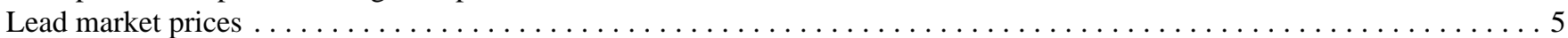

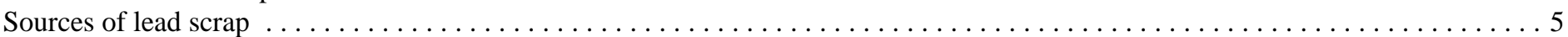

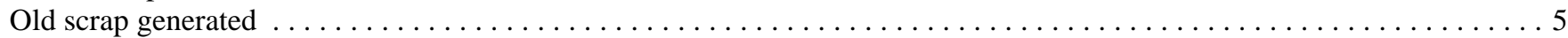

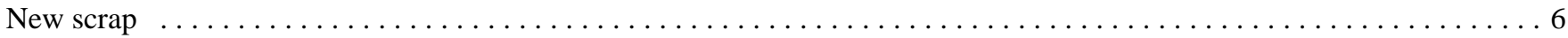

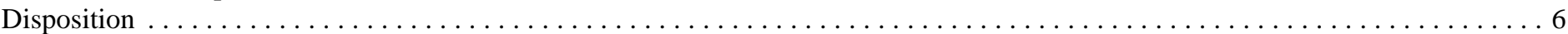

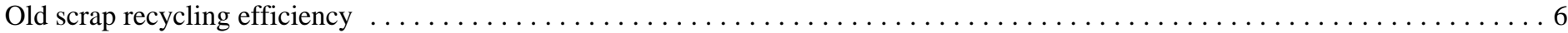

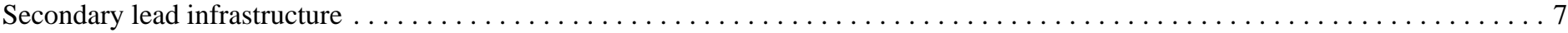

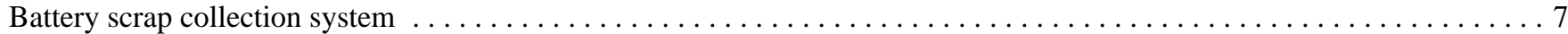

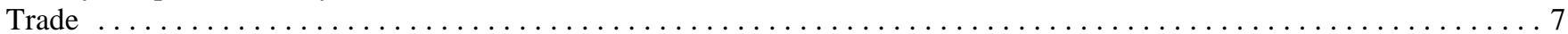

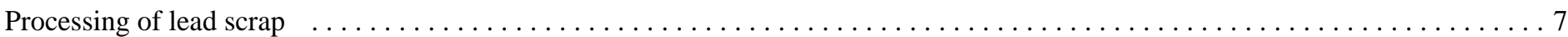

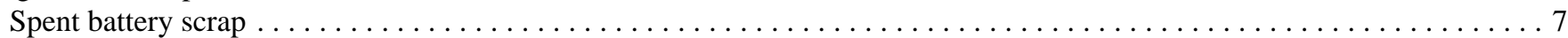

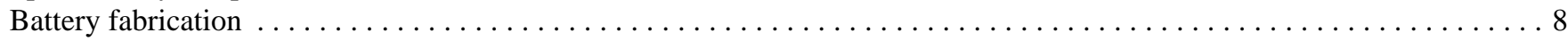

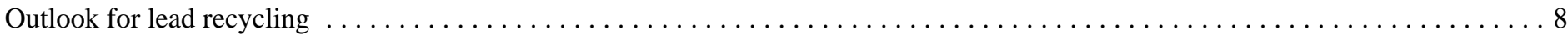

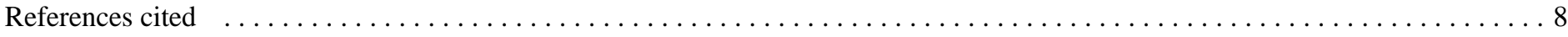

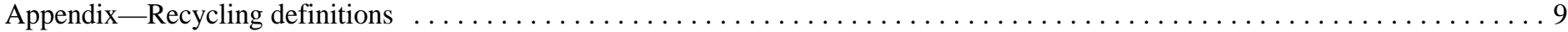

\section{FIGURES}

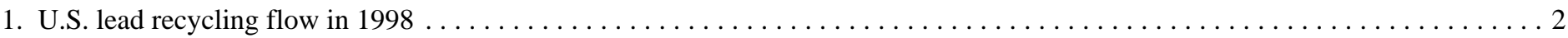

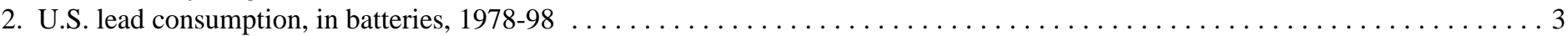

3. U.S. lead consumption, by end use, nonbattery uses, $1978-98 \ldots \ldots \ldots \ldots \ldots \ldots \ldots$

\section{TABLE}

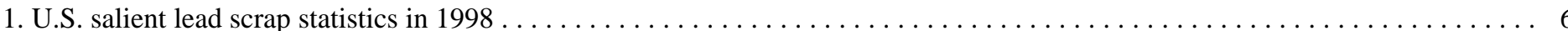




\title{
FLOW STUDIES FOR RECYCLING METAL COMMODITIES IN THE UNITED STATES
}

\section{Lead Recycling in the United States in 1998}

\author{
By Gerald R. Smith
}

\begin{abstract}
This materials flow study includes a description of lead supply and demand factors for the United States to illustrate the extent of lead recycling and to identify recycling trends. Understanding the system of materials flow from source to ultimate disposition can assist in improving the management of the use of natural resources in a manner that is compatible with sound environmental practices. The quantity of lead recycled in 1998, as a percentage of apparent lead supply, was estimated to be about $63 \%$, and recycling efficiency, to be $95 \%$. Of the total lead consumed in products for the U.S. market in 1998, an estimated $10 \%$ was consumed in products in which the lead was not readily recyclable.
\end{abstract}

\section{INTRODUCTION}

Figure 1 illustrates the flow of lead in the United States during 1998. The sources of lead supply and the distribution of these supplies are quantified in this illustration so as to determine specific information on recycling, including lead scrap recycling efficiency and lead scrap recycling rate. As an introduction prior to specific discussion of the components of figure 1, the following background on lead, including its history, important uses and use trends, geological occurrence, production processes and market prices is discussed.

\section{HISTORY AND USE PATTERNS}

Lead is a very corrosion-resistant, dense, ductile, and malleable blue-gray metal that has been used for at least 5,000 years. Early uses of lead included building materials, pigments for glazing ceramics, and pipes for transporting water. The castles and cathedrals of Europe contain considerable quantities of lead in decorative fixtures, roofs, pipes, and windows (Shea, 1996, p. 1). Lead scrap has represented a portion of lead supply in the United States since the 1800's. The earliest known report of consumption of lead scrap was between 1867 and 1889, when a total of about 11,000 metric tons ( $\mathrm{t}$ ) of lead scrap were imported for unspecified uses in the United States (Kirchhoff, 1894). Actual U.S. production of lead from scrap was first reported in 1907. In the following 2 years, about 77,000 t of recycled lead were recovered (Siebenthal, 1911, p. 187). The recovery of lead from scrap increased significantly in the United States during the next 18 years, and by 1927, nearly 252,000 t of lead was recovered from scrap; this represented an estimated $27 \%$ of the total refined lead consumed (Smith, 1930, p. 341). By 1980, the quantity recovered had reached 675,000 t, which was about $63 \%$ of the total refined lead consumed (Rathjen, 1981, p. 480), and by 1998, it had risen to 1.12 million metric tons (Mt), which was 69\% of consumption (Smith, 2000).

Prior to the early 1900's, uses of lead in the United States were primarily for ammunition, brass, burial vault liners, ceramic glazes, leaded glass and crystal, paints or other protective coatings, pewter, and water lines and pipes. The advent of the electrical age and communications, which were accelerated by technological developments in World War I, resulted in the addition of bearing metals, cable covering, caulking lead, solders, and type metal to the list of lead uses. With the growth in production of public and private motorized vehicles and the associated use of starting-lighting-ignition (SLI) lead-acid storage batteries and terne metal for gas tanks after World War I, demand for lead increased. Most of these uses for lead continued to increase with the growth in population and the national economy. Contributing to the increase in demand for lead was the use of lead as radiation shielding in medical analysis and video display equipment and as an additive in gasoline, the latter use peaking in the late 1970's when environmental bans on leaded gasoline were introduced.

Figures 2 and 3 show the trends in consumption of lead in the United States since 1978. By the mid-1980's, a significant shift in lead end-use patterns had taken place. The demand for lead in SLI-type batteries grew rapidly, and this growth continued into the 1990's (fig. 2). In addition, the demand for lead in non-SLI battery applications also grew. Non-SLI battery applications include motive sources of power for airport ground equipment, industrial forklifts, mining equipment, and a variety of nonroad utility vehicles, as well as stationary sources of power in uninterruptible electric power systems for computer and telecommunications networks, and hospitals, and load-leveling equipment for electric utility companies. The use of lead in nonbattery products declined as battery demand increased (fig. 3). 


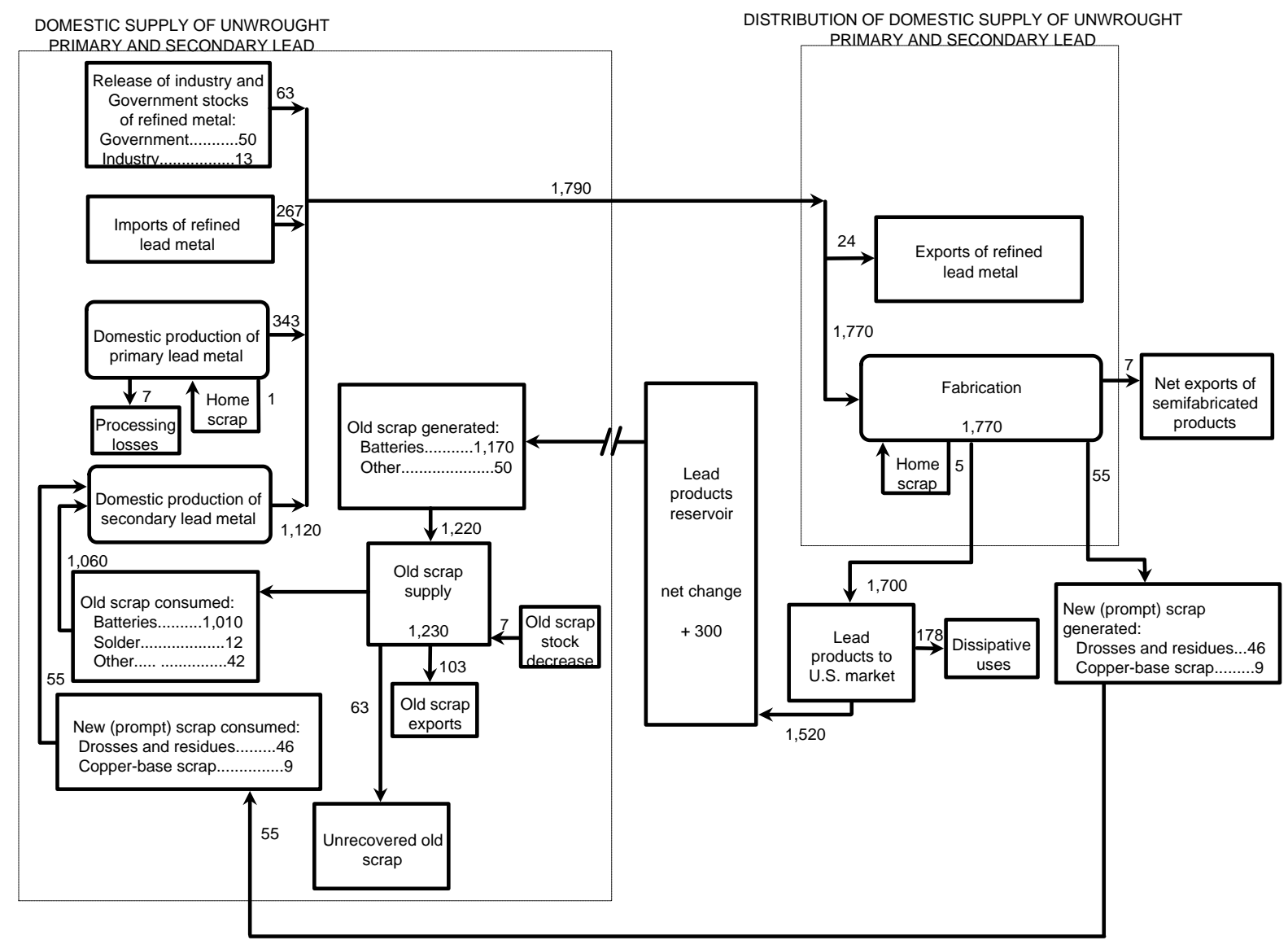

Figure 1. U.S. lead material flow in 1998 (thousand metric tons).

Much of the decline in nonbattery use of lead was a result of the U.S. lead consumers compliance with environmental regulations that significantly reduced or eliminated the use of lead in products that included gasoline, paints, solders, and water systems. Data for consumption of lead as chemical additives in gasoline were estimated for the period 1987 through 1995. The U.S. Environmental Protection Agency (EPA) issued a direct final rule that prohibits the use of such additives in highway vehicles effective January 1, 1996 (U.S. Environmental Protection Agency, 1996). By 1998, the total demand for all types of lead-acid storage batteries represented a record high $88 \%$ of apparent U.S. lead consumption. Other significant uses included ammunition (3\%), oxides in glass and ceramics (3\%), casting metals (2\%), and sheet lead (1\%). The remainder was consumed in bearing metals, brass and bronze billets, covering for cable, caulking lead, extruded products, and solders. U.S. lead consumption in 1998 was about $29 \%$ of total world consumption of lead. The end-use patterns for lead in the remainder of the world were similar to that of the United States, with batteries being the predominant enduse sector (International Lead and Zinc Study Group, 1999, p. 23-34).

The domestic demand for refined lead, by industrial sector in 1998, was principally in the transportation industry as component material for batteries, fuel tanks, seals, solders, and wheel weights and in the communication, construction, electrical, and electronic industries in such products as batteries, cable covering, extruded shapes, pipes, and radiation shielding. A small amount of lead also was consumed for use by producers of ceramics, crystal glass, and specialized chemicals.

\section{GLOBAL GEOLOGIC OCCURRENCE OF LEAD}

Conventional deposits of primary lead and zinc are separable into five principal types that are based, for the most part, on differences in their geologic environments. The following definitions and descriptions of these deposits are from Briskey and Wedow (1986) and J.A. Briskey (U.S. Geological Survey, written commun., 2000). 


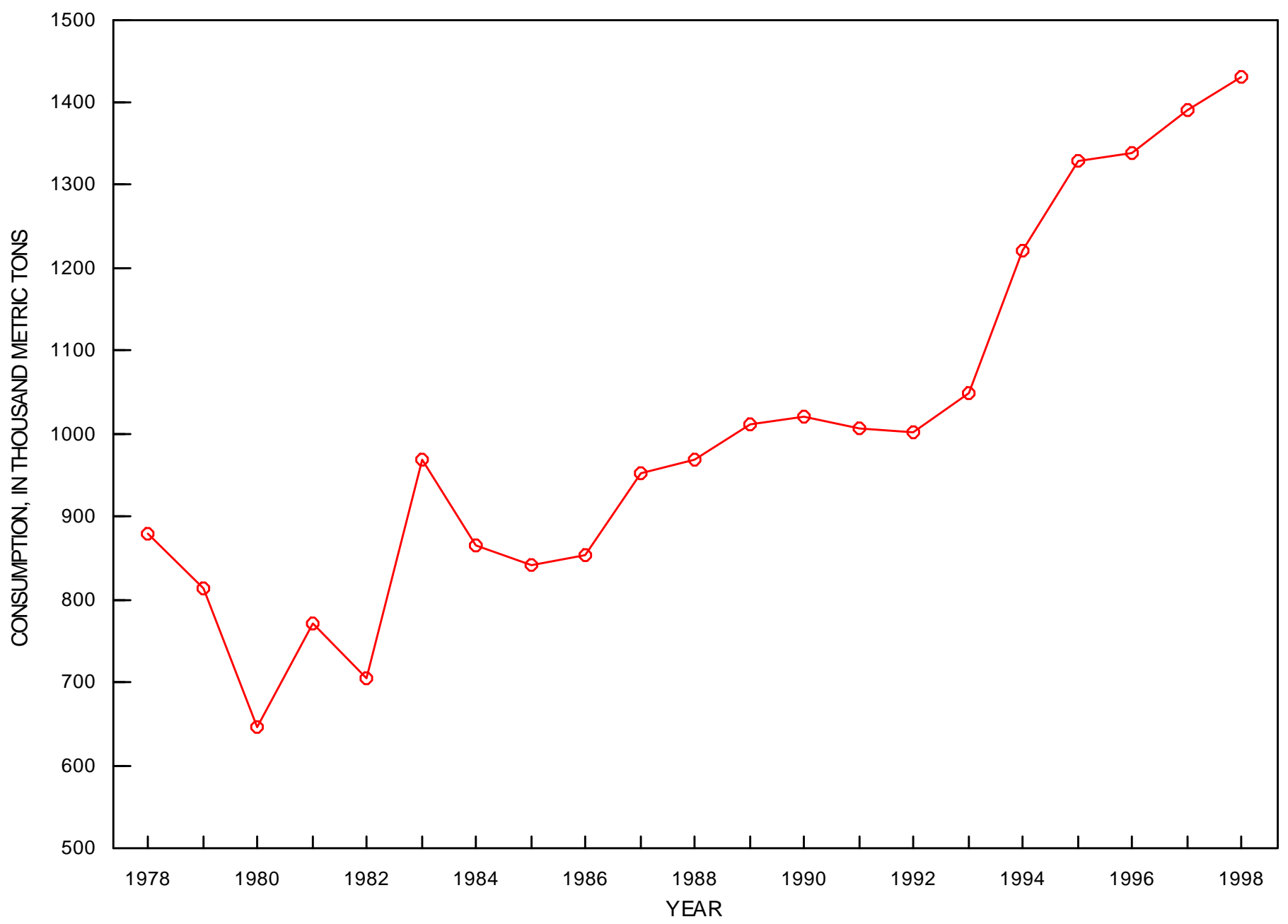

Figure 2. U.S. lead consumption in batteries, 1978-98.

C Volcanic-hosted submarine exhalative massive sulfide deposits comprise almost entirely pyrite and pyrrhotite (iron sulfides) with varying proportions and amounts of sphalerite (zinc sulfide), galena (lead sulfide), chalcopyrite (copper and iron sulfide), and silver-bearing minerals. Lists of minerals in this geologic section are approximately in order of decreasing abundance. The sulfide minerals typically occur as multiple stratiform lenses within submarine volcanic rocks and commonly overlie or are adjacent to discordant feeder zones that contain smaller amounts of these minerals as stringers and disseminations in altered volcanic rocks. Large examples of these deposits include those found in Canada, Cyprus, Japan, Tasmania, and Turkey.

C Sediment-hosted submarine exhalative deposits consist of stratiform basinal accumulations mainly of fine-grained pyrite and (or) pyrrhotite, sphalerite, galena, sporadic barite (barium sulfate), and minor chalcopyrite interbedded with euxinitic marine sediments, which include black shales, siltstones, sandstones, cherts, dolostones (calcium magnesium carbonate), and micritic limestones (calcium carbonate). Large examples of these deposits are found in Australia, Canada, Germany, and the United States (Alaska).

C Strata-bound carbonate-hosted deposits, which are commonly referred to as "Mississippi Valley type," contain mostly sphalerite, galena, pyrite, barite, fluorite (calcium fluoride), and chalcopyrite. These minerals typically fill primary and secondary voids developed in favorable beds or horizons within thick sequences of platform dolostones and limestones. Important examples of these deposits are found in the Mississippi Valley and adjacent regions of the United States, which include the Upper Mississippi Valley, the Tri-State Region (Kansas-Missouri-Oklahoma), southeastern Missouri, and the central and east Tennessee districts; they also are found in the Alps in southern Europe, Canada, and Poland. 


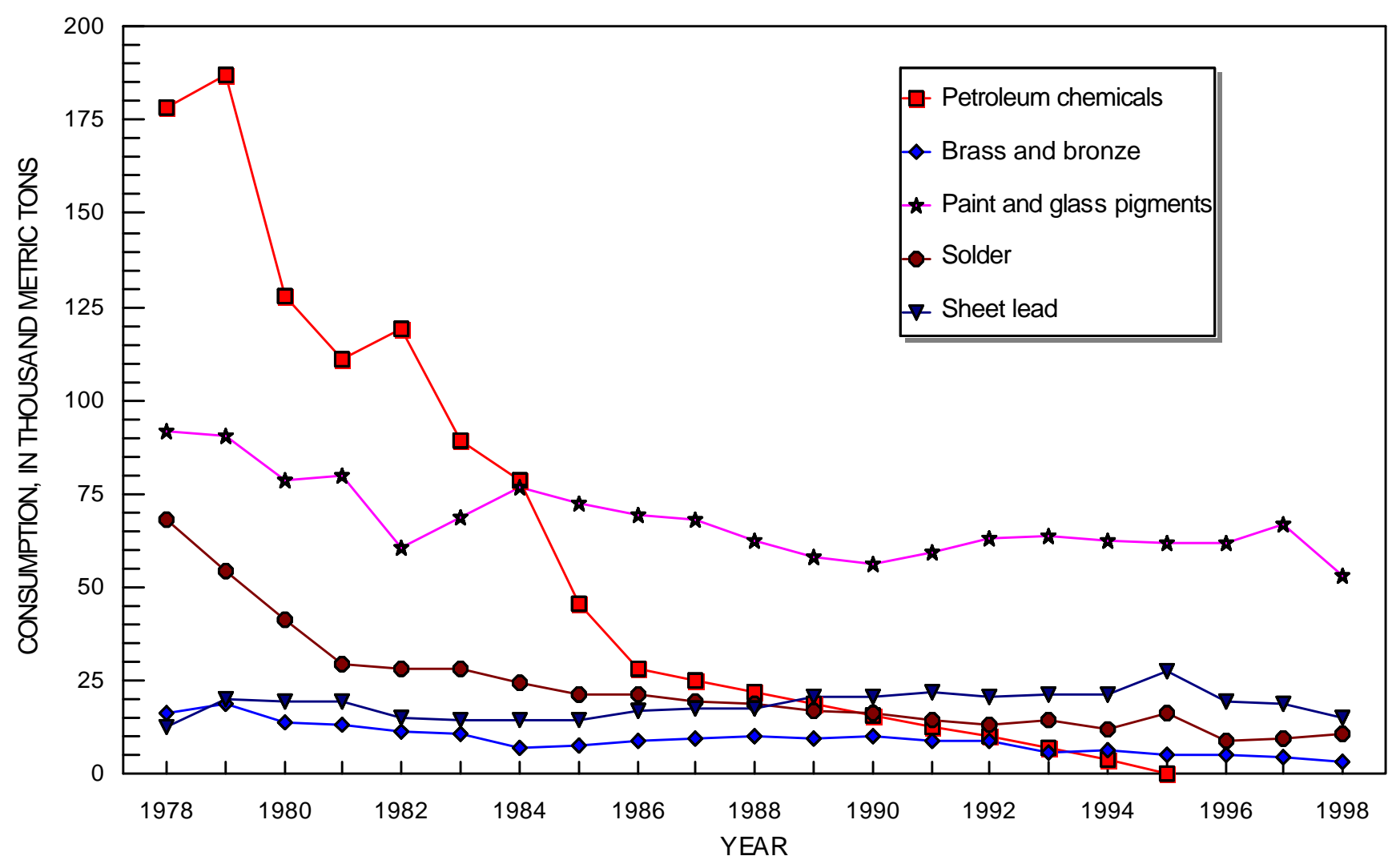

Figure 3. U.S. lead consumption, by end use, nonbattery uses, 1978-98.

C Sandstone-hosted deposits typically are strata-bound and commonly are stratiform concentrations of mainly fine-to-medium crystalline galena with sporadic smaller amounts of sphalerite, pyrite, barite, fluorite, and minor chalcopyrite. These minerals usually occur as clots and disseminations that in aggregate form multiple, thin, sheetlike ore bodies within marine, terrigenous, and continental sandstones, conglomerates, grits, and siltstones. Important examples of these deposits are found in Canada, France, Morocco, and Sweden.

C Vein, replacement, and contact metasomatic deposits typically comprise coarse crystalline aggregates of pyrite, sphalerite, galena, and chalcopyrite, as well as a large number of complex base- and precious-metal sulfide minerals that include those containing abundant arsenic and antimony. Most deposits form multiple, tabular-to-podiform, or pipe-shaped ore shoots or occur as extensive, highly irregular, branching masses. Deposits occur in clusters (districts) that are spatially and temporally related to nearby granitic plutons of granodioritic or quartz monzonitic composition. Contact metasomatic deposits are restricted mostly to the contact aureoles of the plutons. Replacement and contact metasomatic ore bodies typically replace carbonate rocks adjacent to the pluton, whereas vein deposits are usually open-space fillings in fractures in a variety of host rocks. Classic examples of these deposits are found in Germany, Japan, Mexico, Peru, and, especially, the Western United States.

\section{LEAD PRODUCTION PROCESS AND GLOBAL PRODUCTION}

The major share of the U.S. mine output of lead in 1998 was derived from production in Alaska and Missouri. Appreciable quantities were also produced from mining operations in Colorado, Idaho, and Montana. Cumulatively, over the last 200 years, $57 \%$ of the U.S. mine 
output of lead was from strata-bound carbonate hosted deposits. Another $40 \%$ was from vein, replacement, and contact metasomatic deposits (Long, DeYoung, and Ludington, 2000, p. 640).

Lead is processed from the mined ore to the concentrate stage through a series of conventional beneficiation steps. After the raw ore is screened, crushed, and ground at the mill, it is chemically treated in a flotation process to separate metal-containing minerals from the waste rock (tailings) and from each other. The resulting lead concentrate is then further processed through sintering, smelting, and refining steps to produce the pure lead metal. Most of the copper, nickel, and other impurities, which include antimony, arsenic, gold, and silver, are removed from the lead in a "dross" layer that forms on the surface of the melt upon cooling.

The lead bullion product from the smelting step is then processed through several molten refining steps to remove the remaining trace impurities that may include antimony, arsenic, bismuth, copper, silver, tellurium, and zinc, which ultimately yields a minimum of $99.97 \%$ pure refined lead. This lead is then cast into various size ingots for sale to end-use consumers. In 1998, mine production of lead was reported in 44 countries; the top 5 accounted for $68 \%$ of the world's total production of 3.1 Mt of lead in concentrates. Australia was the largest producer with $20 \%$ of the world total, followed by China, 18\%; the United States, 16\%; Peru, 8\%; and Canada, 6\%.

\section{LEAD MARKET PRICES}

Refined lead prices declined throughout most of 1998. The average London Metal Exchange and North American Producer prices per pound were $\$ 0.240$ and $\$ 0.453$, respectively, which were down by $\$ 0.043$ per pound and $\$ 0.013$ per pound, respectively, compared with those of the previous year. In 1998 , recycled lead sold for an average $\$ 0.483$ per pound, which was down by $\$ 0.012$ per pound compared with that of 1997 (Platt's Metals Week, 1999). The market price for whole scrap lead-acid batteries, which is a principal source of lead for recycling, ranged between $\$ 0.045$ and $\$ 0.065$ per pound, which translated to a lead price of $\$ 0.09$ to $\$ 0.13$ per pound assuming that the average amount of lead in such batteries is about 50\% (Worden, 1998). Soft lead scrap from other sources averaged $\$ 0.195$ per pound (American Metal Market, 1999).

In the late 1980's and early 1990's, lead prices generally increased as the lead producing industry continued to adjust effectively to environmental regulations imposed a few years earlier. After a brief decline, prices rose steadily from 1992 to 1996 as a result of the increasing demand in the replacement automotive battery sector. In 1997 and 1998, the price of lead showed some softness owing to 2 consecutive years of moderate temperatures in the more-populated regions of the United States that reduced the failure rate of automotivetype batteries and the subsequent need for replacement batteries.

\section{SOURCES OF LEAD SCRAP}

Sources of new and old scrap are key features of the U.S. lead materials flow diagram that is shown in figure 1. Statistical data for the various types of old and new scrap processed into refined lead metal for domestic consumption were derived from specific information provided to the U.S. Geological Survey (USGS) by the lead recycling (secondary) industries.

The domestic supply of primary and secondary refined lead, as shown in figure 1, consists of primary and secondary refinery production, net imports of refined lead, sales of lead from the Government stockpile, and net releases of industry stocks. Data on trade and Government stockpile sales were obtained from the U.S. Census Bureau and the U.S. Defense National Stockpile Center, respectively, through monthly reports issued by the agencies.

The salient lead scrap statistics discussed in this report for calendar year 1998 (table 1) are based primarily upon information received from lead industry producers and consumers through industry surveys submitted to the USGS. Statistics received through these surveys provided about $99 \%$ of the total production of refined lead reported and $96 \%$ of the apparent consumption of lead.

\section{OLD SCRAP GENERATED}

The key component of the lead recycling industry in the United States is the reprocessing of spent lead-acid batteries. In 1998, approximately $88 \%$ of these spent batteries were of the SLI automotive type, which had an average life of about 4 years; $8 \%$ were of the motive power type, which had an average life of 6 years; and 4\% were of the stationary type, which had an average life of 10 years (Battery Council International, 1998, p. 3). The calculated quantity of old scrap generated in 1998 was assumed to have originated from lead consumed in the manufacture of batteries of the SLI automotive type in 1994, the motive power type in 1992, and the stationary type in 1988. An estimated $97 \%$ of all the old lead scrap generated in 1998 was from spent lead-acid storage batteries. The remainder was from metal sources, such as castings, sheet, solders, and miscellaneous fabricated parts. 
Table 1. U.S. salient lead scrap statistics in 1998

[Thousand metric tons, lead content, unless otherwise specified]

Old scrap:

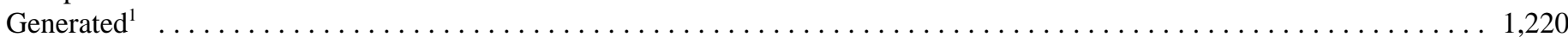

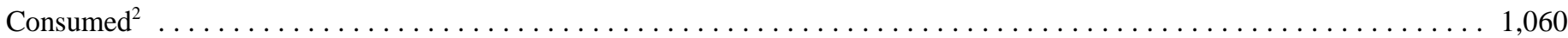

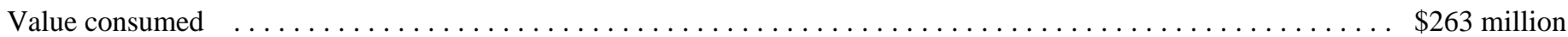

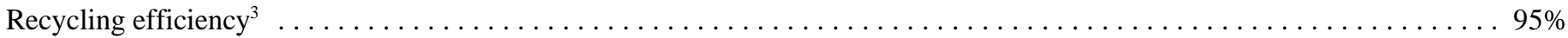

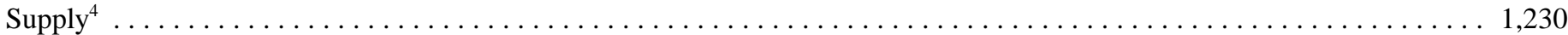

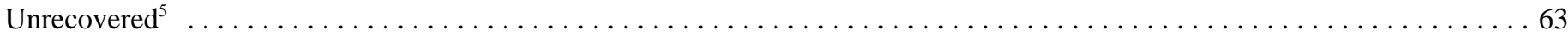

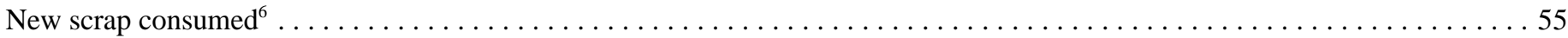

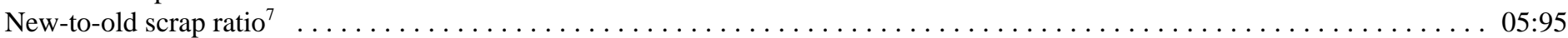

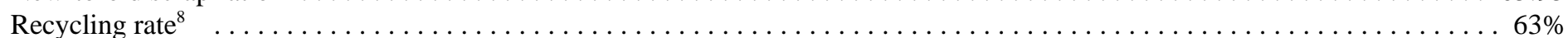

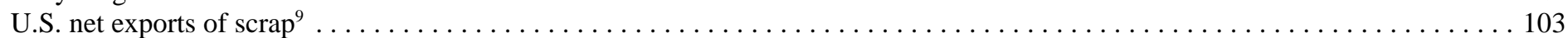

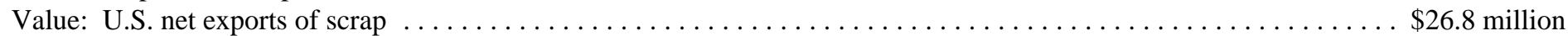

${ }^{1}$ Metal content of products theoretically becoming obsolete in the United States in 1998. Net U.S. imports of finished products that contain lead in the year of consumption may be taken into consideration. It excludes dissipative uses.

${ }^{2}$ Commodity content of products that were recycled in 1998.

${ }^{3}$ (Old scrap consumed plus old scrap exported) divided by (old scrap generated plus old scrap imports plus old scrap stock decrease or minus old scrap stock increase).

${ }^{4}$ Old scrap generated plus old scrap imports plus old scrap stock decrease.

${ }^{5}$ (Old scrap generated plus old scrap imports plus old scrap stock decrease) minus old scrap consumed minus old scrap exports minus old scrap stock increase.

${ }^{6}$ Prompt industrial scrap (excluding home scrap).

${ }^{7}$ Ratio of quantities consumed, in percent.

${ }^{8}$ This is the fraction of supply that is scrap on an annual basis. It is defined as old plus new scrap consumed divided by apparent supply (primary plus secondary production (old plus new scrap) plus imports minus exports plus adjustment for Government and industry stock changes), in percent.

${ }^{9}$ Trade in scrap is assumed to be principally old scrap.

\section{NEW SCRAP}

The quantity of refined lead recovered from new scrap was estimated from the gross weight of purchased drosses and residues reported to the USGS as a source of scrap by the lead recycling industries. An additional source of new lead scrap was that contained in copper-base alloys. New scrap consumed in 1998 was estimated to be $55,000 \mathrm{t}$, or about $5 \%$ of total scrap consumed.

\section{DISPOSITION}

In 1998 , recycled lead represented nearly $77 \%$ of refined lead production in the United States. The spent lead-acid battery is the dominant source of lead for reprocessing by the secondary lead industries. Thus, the efficiency with which these batteries are collected, reprocessed, and returned to the marketplace in the form of refined lead is of prime importance in maintaining the required supply of lead in the United States.

\section{OLD SCRAP RECYCLING EFFICIENCY}

Recycling efficiency shows the relation between what is theoretically available for recycling and what is and is not recovered. By definition, this relation is the amount of old scrap consumed plus old scrap exports divided by the sum of old scrap generated and old scrap imports plus or minus old scrap stock changes. Each component used to determine the relation is considered in terms of the recoverable metal content. A recycling efficiency of about $95 \%$ was reached in 1998 consistent with the organized infrastructure that exists in the United States for collection and recovery of lead scrap and, in particular, spent lead-acid batteries.

\section{SECONDARY LEAD INFRASTRUCTURE}

In 1998, about $98 \%$ of all recycled lead was produced by 9 companies operating 17 battery recycling plants in Alabama, California, Florida, Georgia, Indiana, Louisiana, Minnesota, Missouri, New York, Pennsylvania, Tennessee, and Texas. The geographical distribution 
of these plants effectively supports the complete network of spent battery sources. Secondary lead production capacity in the United States is estimated to be about 1.1 million metric tons per year.

\section{BATTERY SCRAP COLLECTION SYSTEM}

An estimated $60 \%$ to $70 \%$ of spent lead-acid batteries are collected for recycling each year by battery manufacturers through sales agreements with major retailers or through reverse distribution systems. The manufacturers typically collect spent batteries from retailers when delivering shipments of new lead-acid batteries. Retailers accumulate these spent batteries in exchange when customers purchase new batteries. Upon collection of the batteries from the retailer, the battery manufacturer, in turn, arranges to recover the lead content of the batteries through tolling agreements with secondary lead smelters. This lead is then returned to the manufacturer as feedstock for the production of new batteries. In cases where the battery manufacturer also owns a secondary smelter, the tolling step is eliminated. The remaining $30 \%$ to $40 \%$ of spent batteries are collected by scrap dealers. These dealers collect from sources other than large retailers, which include small retailers, service stations, and junk yards, subsequently offering the batteries for sale on the open market.

\section{TRADE}

As a net exporter of lead scrap, the United States sent 103,000 $\mathrm{t}$ abroad in 1998; about 91\% went to Canada. Other countries that received appreciable quantities of lead scrap from the United States included Belgium, China, Hong Kong, India, Japan, Mexico, Sweden, Taiwan, and the United Arab Emirates. The exported scrap was principally in the form of battery and nonbattery metal scrap, which included approximately 5,000 t of lead contained in whole spent batteries. The remaining scrap (about 9\%) was exported in the form of ash and residues. Exports of lead scrap represented about $39 \%$ of the total exports of lead-containing materials, which included base bullion, concentrates, and wrought and unwrought lead and lead alloys.

\section{PROCESSING OF LEAD SCRAP}

\section{SPENT BATTERY SCRAP}

The processing of spent batteries is carried out in a series of steps that includes draining the battery acid, dismantling the battery by hammer mill and grinding procedures, washing and tumbling the dismantled battery to separate its component parts (generally by screening and gravity separation steps), and, finally, treating the individual component parts for recovery and reuse. In the processing of the lead-acid battery, most of its components are recovered for reuse. The lead-containing components recovered from the battery consist of lead alloy from the grids and posts, lead oxides from the electrode paste, and other lead compounds from the battery cell reactions. Typically, the lead-bearing paste is first desulfurized and combined with the lead-bearing grids and posts as a feed to a reverberatory furnace; this yields a raw lead product and a slag that contains $20 \%$ to $40 \%$ lead. The slag is fed to a blast furnace or electric reduction furnace where the lead content is recovered as raw lead product. The raw lead products from these furnaces are then melted in refining kettles to remove residual impurities, adjusted to customer specifications, and cast into ingots for shipment. In some facilities, the grids and posts are treated separately from the paste. In such operations, a rotary furnace that produces desired alloys for new battery production directly from the used grids and posts is used.

The manner in which the sulfuric acid recovered from the batteries is treated to produce usable products, such as fertilizers, laundry detergent and paper processing ingredients, regenerated electrolyte for use in new batteries, and a $\mathrm{pH}$ control solution for use in the wastewater treatment system at the recycling facility, depends upon the particular recycling facility. The shredded polypropylene plastic battery casings are converted to plastic pellets onsite or shipped to a plastics recycler for eventual reuse in the production of new battery casings. Nonplastic components of the battery, such as rubber casing material and grid separators, may be used as reducing agents in the melting process for recovery of lead.

Loss of lead is minimal in the processing of spent batteries. Environmental regulations in place for secondary lead smelters require that the loss of lead in these operations be significantly restricted. In June 1997, the EPA issued a direct final rule that amended certain components of the existing national emission standards for hazardous air pollutants from secondary lead smelting. This direct final rule, as amended, established standards to limit hazardous air pollutant emissions from agglomerating furnaces, dryers, fugitive dust sources, refining kettles, and smelting furnaces at lead smelters (U.S. Environmental Protection Agency, 1997).

\section{BATTERY FABRICATION}

Battery manufacturers recover essentially all the scrap, which is mostly grid and post trimmings, generated in the battery assembly process. This home scrap is collected and remelted for use in the fabrication of more grids and posts. Minimal scrap or waste is generated in the production of the electrode paste. The small quantity that is recovered is reused as home scrap. 


\section{OUTLOOK FOR LEAD RECYCLING}

The recycling efficiency level of $95 \%$ achieved in 1998 is likely to continue into the foreseeable future. Because the recycling efficiency is, however, already quite high, any further increase will be slight. Likewise, the recycling rate of $63 \%$ also is expected to remain at a high level. Only a decline in the demand for lead, thus lessening the need for primary material, is likely to raise it significantly. Such factors as environmental controls on lead, rising lead demand in the replacement battery sector, and the integral and appreciable role that the secondary lead industry plays in meeting overall U.S. demand for lead will continue to support significant recycling of lead. Continued high levels of lead recycling enhance the sustainability of lead production and result in greater conservation of energy and resources.

On an international level, interest in lead recycling has been continuous and extensive. Increasing environmental concerns have prompted the institution of additional regulations on new lead production that have resulted in additional pressure and incentive to increase the recycling of lead in many countries around the world. Recycled lead now accounts for about one-half of the refined lead produced worldwide each year (International Lead and Zinc Study Group, 1995, p. 15).

Forecasts for lead recycling indicate that an additional $1 \mathrm{Mt}$ of secondary lead capacity will be required worldwide by 2008 . The feed source for this capacity increase essentially will be that of the spent lead-acid batteries obtained from the ever-expanding vehicle population throughout the world. In those regions where the vehicle population is expanding to the greatest extent, however, challenges are expected to remain in achieving significant increases in recycling efficiency. Specifically, the collection of the spent automotive-type batteries and their transportation to appropriate recycling facilities will require the resolution of certain restrictions to battery recycling as outlined in the Basel Convention (International Lead and Zinc Study Group, 1998, p. 12).

\section{REFERENCES CITED}

American Metal Market, 1999, U.S. prices of smelters' scrap lead: American Metal Market, v. 107, no. 160, August 19, p. 3.

Battery Council International, 1998, National recycling rate study: Chicago, IL, Battery Council International (Prepared by Smith, Bucklin and Associates), December, $19 \mathrm{p}$.

Briskey, J.A., and Wedow, H., Jr., 1986, Zinc resources, in Bever, M.B., ed., Encyclopedia of materials science and engineering: Oxford, Pergamon Press, p. 5539-5541.

International Lead and Zinc Study Group, 1995, Recycling lead and zinc into the 21st century, in International Recycling Conference, 6th, Madrid, June 18-23, 1995, Proceedings: International Lead and Zinc Study Group, 330 p.

1998, Environmentally friendly lead and zinc-The challenge of the recycling millennium, in International Recycling Conference, 7th, Toronto, May 25-29, 1998, Proceedings: International Lead and Zinc Study Group, 162 p. 1999, Lead and zinc statistics: International Lead and Zinc Study Group, v. 39, no. 12, December, 67 p.

Kirchhoff, C., 1894 [1895], Lead, in Mineral resources of the United States 1893: Miscellaneous Documents of the House of Representatives for the Second Session of the Fifty-Third Congress, 1893-94, v. 28, no. 181, p. 89-102.

Long, K.R., DeYoung, J.H., Jr., and Ludington, Steve, 2000, Significant deposits of gold, silver, copper, lead, and zinc in the United States: Economic Geology, v. 95, no. 3, p. 629-644.

Platt's Metals Week, 1999, Annual metal averages for 1998: Platt's Metals Week, v. 70, no. 8, February 22, p. 4.

Rathjen, J.A., 1981, Lead, in Metals and minerals: U.S. Bureau of Mines Minerals Yearbook, 1980, v. I, p. 479-505.

Shea, E.E., 1996, Lead regulation handbook: Rockville, MD, Government Institutes Inc., 240 p.

Siebenthal, C.E., 1911, Lead, in Metals: U.S. Geological Survey Mineral Resources of the United States 1909, pt. I, p. 181-201.

Smith, G.R., 2000, Lead, in Metals and minerals: U.S. Geological Survey Minerals Yearbook 1998, v. I, p. 44.1-44.24.

Smith, L.A., 1930, Lead, in Metals: U.S. Bureau of Mines Mineral Resources of the United States 1927, pt. I, p. 341-372.

U.S. Environmental Protection Agency, 1996, Prohibition on gasoline containing lead or lead additives for highway use: Federal Register, v. 61, no. 23, February 2, p. 3832.

1997, National emission standards for hazardous air pollutants from secondary lead smelting —Direct final rule—Amendments to rule: Federal Register, v. 62, no. 114, June, 13, p. 32209.

Worden, Edward, 1998, Lead battery market varies: American Metal Market, v. 106, no. 241, December 17, p. 7. 


\section{APPENDIX-DEFINITIONS}

apparent consumption (AC). Primary plus secondary production (old scrap) plus imports minus exports plus adjustments for Government and industry stock changes.

apparent supply (AS). AC plus consumption of new scrap (CNS).

dissipative use. A use in which the metal is dispersed or scattered, such as paints or fertilizer, making it exceptionally difficult and costly to recycle.

home scrap. Scrap generated as process scrap and consumed in the same plant where generated.

new scrap. Scrap produced during the manufacture of metals and articles for intermediate and ultimate consumption; it includes all defective finished or semifinished articles that must be reworked. Examples of new scrap are clippings, turnings, borings, skims, drosses, and castings. This includes scrap generated at facilities that consume old scrap. Included as new scrap is prompt industrial scrap obtained from a facility separate from the recycling refiner, smelter, or processor. Excluded from new scrap is home scrap that is generated as process scrap and used in the same plant.

new-to-old scrap ratio. New scrap consumption compared with old scrap consumption measured in weight and expressed as a percentage of new plus old scrap consumed; for example, 40:60.

old scrap. Scrap that includes, but is not limited to, metal articles that have been discarded after serving a useful purpose. Typical examples of old scrap are electrical wiring, lead-acid batteries, silver from photographic materials, metals from shredded cars and appliances, used aluminum beverage cans, spent catalysts, and tool bits. This is also referred to as "postconsumer scrap" and may originate from industry or the general public. Expended or obsolete material that is used dissipatively, such as paints and fertilizer, are not included.

old scrap generated. Metal content of products theoretically becoming obsolete in the United States in the year of consideration; this excludes dissipative uses.

old scrap recycling efficiency. Amount of old scrap recovered and reused relative to the amount available to be recovered and reused. Defined as [consumption of old scrap (COS) plus exports of old scrap (OSE)] divided by [old scrap generated (OSG) plus imports of old scrap (OSI) plus a decrease in old scrap stocks (OSS) or minus an increase in old scrap stocks] measured in weight and expressed as a percentage; that is, x 100

OSG + OSI + OSS decrease or - OSS increase.

old scrap supply. Old scrap generated plus old scrap imports plus old scrap stock decrease; that is, OSG + OSI + OSS decrease.

old scrap unrecovered. Old scrap supply minus old scrap consumed minus old scrap exported minus old scrap stock increase.

price. Total value of old lead scrap consumed calculated on the bases of an estimated value for the lead contained in whole battery scrap plus $75 \%$ of the unit value of primary lead for all other forms of lead scrap. The total value of old lead scrap exports was based upon the value for the gross weight of lead scrap as reported by the U.S. Bureau of the Census.

recycling. Reclamation of a metal in usable form from scrap or waste. This includes recovery as the refined metal or as alloys, mixtures, or compounds that are useful. Examples of reclamation are recovery of alloying (or other base metals) in steel, recovery of antimony in battery lead, recovery of copper in copper sulfate, and even the recovery of a metal where it is not desired, but can be tolerated, such as tin from tinplate scrap that is incorporated in small quantities (and accepted) in some steels, only because the cost of removing it from tinplate scrap is too high and/or tin stripping plants are too few. In all cases, what is consumed is the recoverable metal content of scrap. 
recycling rate. Fraction of the metal apparent supply that is scrap, on annual basis. It is defined as consumption of old scrap plus consumption of new scrap divided by apparent supply measured in weight and expressed as a percentage; that is,

$$
\text { [(COS + CNS }) / A S] \text { x } 100 \text {. }
$$

scrap consumption. Scrap added to the production flow of a metal or metal product. 